\title{
Bom Retiro 958 metros - geografia da memória e memória poética
}

Somos portadores de um saber inconsciente. Não dispomos daquilo que sabemos de maneira voluntária, e conhecemos a experiência de algo que nos escapar à medida que procuramos nos lembrar dele ou acioná-lo para fins práticos. Contudo, se escutamos nossos lapsos de linguagem e os tomamos em consideração, percebemos aí a manifestação de um sujeito que fala e pode reconhecer naquilo que foi dito um saber. Um saber que não estava proposto narrativamente, um saber que não detinha uma sintaxe muito evidente, um saber que, principalmente, pode falar ao contrário daquilo que enxergamos como nosso ponto de vista, nossa posição no mundo desperto, seja ela afetiva, político-ideológica, profissional e o que mais se queira nomear como campo de ação dos homens. Este saber pode mudar de maneira contundente os rumos de uma conversa, a nossa apreciação sensível do mundo que está ao redor, detonar um processo criativo sem precedentes, enfim, pode fazer a roda girar sem que o sujeito que foi seu criador consiga deter alguma coisa deste movimento inexorável. Principalmente, este saber se produz em ato, de palavra falada ou escrita, deixando sua condição inconsciente se desvelar ao próprio sujeito e ao público leitor. O texto que segue é fruto de uma atitude afinada com este proceder, ou seja, ele não foi estrategicamente pensado antes. Sua lógica se revela no fim de sua confecção e se corrige minimamente para não esconder (recalcar) o caráter fragmentário da origem desta reflexão, que tenta preservar o impacto de assistir BOM RETIRO 958 METROS.

Não à toa, começo por dizer uma lembrança que escapa. Dentre os campos mais privilegiados de ação do saber inconsciente está a memória, com seu mundo infinito de arquivos mal dispostos à ação de um bibliotecário exigente. Fruto da ação de um mecanismo chamado recalque, a maneira pela qual constituímos nosso acervo pessoal de recordações é altamente deformada. Recalcamos aquilo que não queremos recordar; deformamos os fatos para lembrá-los de forma melhor, ou seja, a nosso 
favor e tendenciosamente. Tudo isso tem a ver com processos primários por meio dos quais opera nosso inconsciente. Nossa memória acaba por armazenar de forma indescritível, e também um tanto inacreditável, acontecimentos, traços de percepção, história de afetos, uma lista infindável de qualidades de coisas que não cabe detalhar ao extremo, nunca. Não avaliamos aquilo que retivemos de uma experiência passada, mas, sem mais, de supetão, uma irrupção dessa "coisa" em nossa vida desperta pode acontecer, associada a algo que afeta nossos sentidos e constitui uma ligação inusual, nova, alegre ou aterradora.

Viver, experimentar as possibilidades de irrupção da memória já fez muita história no mundo ocidental. O lugar sagrado da memória está cingido pela ideia potentíssima de que ele é lugar da verdade. A associação forte que junta memória e verdade, memória subjetiva e verdade do sujeito, memória que determina os passos deste sujeito no mundo e, portanto, memória que pode ser tomada como realidade para este sujeito, tem consequências para o mundo e também para o sujeito. Nada é mais relativo que esta realidade "subjetiva", porque acreditamos em coisas cuja origem não tem nada de verdade objetiva ou científica ou, muitas vezes não há nada ou quase nada de compartilhável na interpretação que alguém faz do mundo e da própria experiência: a versão do outro, para dizer o mínimo, nunca é a mesma, quando não é afrontosamente diferente. Podemos inclusive ser o outro de nós mesmos; a irrupção de uma lembrança atesta isso. Isso vale para falarmos de uma experiência "acontecida" no universo da arte, algo que nos atravessa pelos caminhos sondáveis e insondáveis do nosso acerto de memória.

A mudança perceptiva que se produz ao longo de uma vida torna a nossa história, ou melhor, a memória que temos dela, um tecido cuja trama se remexe com certa constância e muda o padrão de seu desenho quase que ininterruptamente. $E$ tudo isso independe de uma ação do sujeito.

Stanislávski no teatro falou de memória afetiva para construir um método de interpretação que visava a um tipo de verdade cênica. Isso fez história. Conjugou memória afetiva e verdade para o trabalho do ator. Outras poéticas também usaram da categoria da verdade para, por exemplo, zerar a representação, como forma de desnudamento da condição da arte, ou do artista, ou da realidade representada. Aqui se extingue a categoria da memória, numa certa denúncia de sua condição de ficção. 
Proust fala do sobressalto que a congruência instantânea entre sensação e memória pode ocasionar. A captura do tempo perdido neste breve lapso de tempo é verdadeira e se esvai, como tudo que é da ordem das manifestações inconscientes. É, segundo ele, um momento de suspensão da morte, afirmando ser isso possível num plano poético.

Cito aqui um trecho de sua biografia escrita por Jean-Yves Tadié: "Ostende se encontra, em Jean Santeuil, sob a forma característica da lembrança, uma vez que Proust vive duas vezes (ao menos): sua existência real, cotidiana, e sua ressurreição pela memória. Não é sobre esta praia belga que ele escreve ou que ele pensa, mas dez anos mais tarde: 'E perto dali, era Ostende onde ele (Jean) tinha estado quando era pequeno (...). Ele experimentava uma sensação muito particular sentindo assim um passado tão diferente se religar ao presente, pensando que ao seguir a margem cinza deste imenso mar cinza ele chegaria a Ostende que era para ele uma praia isolada do resto do mundo.' E assim, se lembrando 'do mar do Norte, do Báltico, de Dieppe', Jean constata que somente a natureza 'fazendo-nos sentir aquilo que já sentimos uma vez, nos conduz diretamente a algum ponto deste mundo fabuloso de nossas lembranças que se tornou o mundo da verdade."' (p. 172) ${ }^{1}$. As citações entre meias aspas são do romance de Proust, Jean Santeuil, que antecede sua obra Em Busca do tempo Perdido.

A citação traça um desenho de como a verdade "se constituii" Um fora do mundo é a sensação da primeira impressão, a mais infantil ou originária. Fazemos o contorno dela de tal maneira que se torna difícil juntá-la à, digamos, geografia do mundo. Mas ela pode reviver e ser realocada num outro mapa que a vida convida (ou obriga) a desenhar. Algo do sentimento primeiro permanece, parcialmente traído é verdade, mas mesmo assim continua a dizer da existência, num locus inconsciente, de uma marca do sujeito com sua substância radicalmente singular.

Nada é isento nestes assuntos.

Em BOM RETIRO 958 METROS, encontro um bairro do Bom Retiro revirado, do avesso. Este preâmbulo sobre a memória não é ocioso. O Bom Retiro é para mim um bairro que faz parte da vida desde a mais tenra infância. Ao acompanhar o espetáculo, vi-me em um lugar do bairro onde jamais estive por tanto tempo: o meio das ruas. Não estava nas calçadas onde costumam circular os pedestres, estava no meio fio, onde passam os carros e o espetáculo do Teatro da Vertigem. E também não estava

1 Jean-Yves Tadié. MARCEL PROUST Biographie. Vol. 1. Paris:Gallimard, 1996. A tradução do excerto é minha. 
nas horas em que costumava estar no Bom Retiro; era noite e o bairro, desde sempre abarrotado de gente, próprio de um centro comercial constituído por imigrantes que anseiam pelo contato com o outro cultural, estava deserto, sombriamente deserto, como que espoliado de seu burburinho ontológico.

Antes de mais nada, é obrigatório que se fale da impecável e complexíssima produção que acompanhamos. Desde o início da narrativa, as várias locações cenográficas, a sonoplastia, a marcação através da qual o público é conduzido, desvelam um detalhamento milimétrico de produção, ao qual, de fato, já estamos habituados ao assistir os trabalhos do grupo. Fico impressionado, por exemplo, com o timing e a ideia de fechar uma rua de trânsito pesado por alguns minutos para realizar uma cena. Em pleno centro de São Paulo!

Choques espetaculares à parte, mas não negligenciáveis no comentário se levarmos em conta a ousadia e a coragem dos gestos da concepção teatral, que é $100 \%$ coerente com a trajetória do Vertigem, o espetáculo leva o espectador para um outro lugar. Outro lugar que não o da sala de teatro, o que é uma marca registrada, mas um lugar tornado outro pela ação artística, um lugar que desta vez é a maior parte do tempo um espaço "entre". O corredor do shopping Cesare Lombroso (grande e sugestivo nome pelo que carrega de História), as ruas do bairro vazias, os muros da estrada de ferro, as lajes de marquises de lojas, a ruína de um teatro que não é mais teatro, mas que volta a sê-lo por alguns minutos, sua fachada, a rua de novo e, last but not least, a última caçamba, que não é a única e onde o público não entra, mas que marca o ponto final de um percurso que colocou o espectador sem proteção diante de um acontecimento que fala de exclusão. O tempo todo!

Os excluídos da polis, em suas diversas versões, frequentam o espetáculo, seja na própria dramaturgia - os imigrantes judeus, bolivianos, coreanos, os sem-teto, os loucos de rua - seja porque o espetáculo, ao acontecer, passa por pedestres ou pedestres passam por ele sem escolha voluntária. Esta, aliás, é uma assertiva: toda cidade tem teatro e ele só pode ser recalcado até certo ponto; toda cidade ao nascer gera sua representação, o teatro é uma delas. Nós o encontramos, nesta trajetória poética, acontecendo em lugares insuspeitos: hospital, igreja, teatro mesmo (!), rio, presídio e rua, irrompendo para nos avisar que a geografia que isola a arte do mundo não vai além da próxima esquina. O poético está nos interstícios do cotidiano e os dois podem ser muito violentos, diga-se de passagem. É preciso "ficcionalizar-se" para se pensar 
de alguma maneira, para introduzir um intervalo de respiração entre o que nos acontece e a nossa percepção disso. A produção simbólica nos ajuda no enfrentamento do real e ela altera de fato este real.

Estar "entre", em contato com o excluído da cidade (que passa a ser um incluído!), seja na forma de personagens emblemáticos da exclusão, seja na forma de figuras absolutamente fictícias como o manequim deformado que busca emprego; estar "entre" sendo levado por uma personagem muda e solitária que, numa cena sentada no ponto de ônibus com seu radinho, é uma pintura de Edward Hopper; estar "entre" não é estar sentado no teatro. Quando isso acontece, estamos numa sala com um cheiro de mofo beirando o insuportável (aliás, BR 3, outro trabalho do Vertigem, trazia a questão do fedor onipresente de um jeito maciço para cima do espectador, algo de entranha sendo posta para fora), mas que já foi teatro e palco de montagens gloriosas e aí o mergulho na história se faz inevitável, como aliás o espetáculo já deu a entender em outras tantas cenas. Para alcançar este teatro sua escadaria para baixo nunca me pareceu tão longa! Estar "entre" é como não estar em algum lugar e isso para a percepção não é algo desprezível. Procurava algum apoio na simpatia dos atores ou na sua diligência em guiar-nos pelo espetáculo, mas dava por mim em insegurança quando percebia a simpatia teatral que estava em jogo.

Chegar ao teatro não apaziguou esta sensação de insegurança. Ônibus passavam pelo espaço entre a entrada do teatro e o público do outro lado da rua. Via-se como o isolamento geográfico do edifício emblemático era pura obra de ficção. Dentro do teatro o que iria acontecer também não parecia lá muito fictício, embora fosse texto encenado com atores... O uso da ruína cria um envoltório de representação bem próxima de um grau zero. Para finalizar a insegurança, o público subia ao palco para ver de pé o apagar das luzes da empreitada, quando começa a faxina literal do espaço, que remete à faxina de uma linguagem isolada demais, bela arte demais, vaidosa demais de suas conquistas.

Um pouco antes deste momento propriamente dentro do teatro, chegamos à cena que para mim é uma culminância deste percurso atormentado, que mistura história (memória) e arte em níveis de significação de tal envergadura que sua totalização só pode acontecer pela via do que chamava no início de verdade do sujeito, ou seja, na mais estreita e miúda singularidade. Estamos diante da fachada do teatro TAIB, na rua Três Rios, bairro do Bom Retiro em São Paulo. Esta fachada tem pelo menos três 
andares, ou mais a contar os planos intermediários de acesso. Ela é toda de vidro, entrecortada por pilares de concreto revestidos. Primeiro a encenação fala da história do lugar: ali era a Casa do Povo, entidade dos imigrantes judeus de esquerda, também foi uma escola, a Scholem Aleichem, cujo nome está escrito em giz nas paredes pretas do palco ao qual teremos acesso depois. Aparecem figuras de judeus ortodoxos de costas. Sobre esta fachada começa a projeção em filme dos chuveiros de gás numa câmara de gás de um campo de concentração nazista. Breve projeção na fachada, para quem passasse na rua, pois nós espectadores estávamos na calçada em frente. Entre o espetáculo e o espectador, pode passar o mundo e sua história.

A descoberta do que era projetado veio de repente para mim, mas é o de repente da memória infiltrada, o de repente de um momento vertiginoso e fugaz de verdade subjetiva. Eu reencontrava ali as inúmeras narrativas que testemunhara ao longo da vida, muito próximo do lugar onde eu as ouvia, ou do lugar onde essas narrativas se formaram. Era um de repente indesejado, violento, que desnudava despudoradamente algo que já está nu há tanto tempo! Sentimento inexorável de mal-estar.

Filho de judeus cujos avós viveram no bairro durante os anos mais difíceis de suas vidas, frequentador fiel em festas religiosas na infância, já adulto espectador de espetáculos no TAIB e, nos últimos 20 anos, público cativo da Pinacoteca do Estado, carrego do bairro uma tonelada de memórias. Narrativas orais de meus antepassados, muitas delas referidas ao cotidiano dos anos 30 e 40 do século passado, relatos de como chegaram as primeiras notícias do genocídio e, sobretudo, o grande e eterno relato da dor que o impacto da SHOAH teve na vida destas pessoas que, apesar de inúmeras tentativas, me considero incapaz de avaliar. Tem algo de irrepresentável, do qual só nos aproximamos à meia verdade. Além destas memórias do trauma, experiências sensoriais associadas à comida, como sói acontecer com um descendente de judeus, vivências pessoais pelas casas, calçadas e sinagogas, enfim, o Bom Retiro é um lugar que foi se integrando a uma geografia que só agora, com este acontecimento teatral e surpreendente para mim, avalio o tamanho afetivo.

A história do Holocausto enseja discussões a respeito de sua irrepresentabilidade: como falar dele sem traí-lo? Como representá-lo sem acalmar o terrível que ele envolve? Como transmiti-lo para evitar que se repita?

Eis que, paradoxalmente, o Teatro da Vertigem encena o irrepresentável e dele se aproxima mais uma vez. A imagem do filme projetada na fachada, a descida ao 
ínfero da ruína do teatro com seus odores correspondentes, o escuro, a meia luz, a cena das costureiras bolivianas com suas máquinas de costura como que flutuando no espaço, a falar de uma escravidão em pleno século 21 (uma antológica representação da solidão, sentimento este tão irrepresentável!), e a volta à superfície para a cena da caçamba onde jazem inertes os manequins que encerraram sua vida útil, mas que ainda falam dela experimentando a morte.

Eis-nos de novo na superfície do mundo.

A arte marca a geografia da memória de maneira indelével, de modo que a cartografia nunca mais seja a mesma, o que de fato ela nunca é. Imaginariamente, congelamos alguma coisa em uma fixidez identitária tão necessária para os embates da vida. São marcas que quando revisitadas geram uma gama de afetos muito variada, do prazer ao desprazer, de alta ou baixa voltagem. A arte afronta tudo isso. Com seu impacto o sujeito se desloca nesta fixidez, a ponto de sentir saudades do estado originário de suas próprias lembranças.

\section{POST SCRIPTUM}

Este não é um texto isento. Desde meu primeiro contato com o trabalho do Teatro da Vertigem, em O LIVRO DE JÓ, encontrei uma tradução daquilo que era uma busca existencial incessante em relação à arte, uma obra que conseguia, ao mesmo tempo, realizar-se (expressar, denunciar, formalizar) e fazer reverberar um sentimento de mal-estar, tanto no que diz respeito à eleição do seu tema como de seus meios como obra de arte. Isso aproximava a arte de algo que é estrutural em psicanálise: o mal-estar não se resolve; dele se fala incessantemente porque é inarredável de nossa condição. Como está no centro de nossa luta cotidiana para sustentar o desejo de viver, podemos dizer que ele é fundante deste desejo, assim como o sujeito falante vive correndo atrás de algo que o diga totalmente e sempre fracassa neste intento.

É desta maneira que aumentamos nossas armas simbólicas, feitas de construções de linguagem, para dar conta de um montante afetivo causador de mal-estar. Importa ressaltar que, por definição, sempre teremos de nos haver com ele. $O$ fascinante é fazer dele um ponto de fuga possível para qualquer obra, não único, mas "bastante" onipresente, de modo a retirar dela qualquer veleidade quanto a uma promessa de felicidade, beleza, e o que mais entrar nesta série de atributos que a humanidade não para de perseguir com certa razão, mas que não cabe à arte refe- 
rendar em seu fazer propulsor. Não é por acaso que BOM RETIRO 958 METROS também tematiza a beleza, no corpo, na moda, da forma mais cruelmente sarcástica, desvelando em sucessivas camadas de "des-encenação", o horror que subjaz ao belo, conforme as palavras de Rilke. 